\title{
Relacje między religia a etnosem w Europie Środkowo-Wschodniej
}

\begin{abstract}
Radosław Zenderowski, Religia a tożsamość narodowa $i$ nacjonalizm $w$ Europie Środkowo-Wschodniej. Między etnicyzacja religii a sakralizacja etnosu (narodu), Fundacja na rzecz Nauki Polskiej, Wroclaw 2011, ss. 315.
\end{abstract}

Recenzowana monografia jest, oprócz rozprawy habilitacyjnej ${ }^{1}$, niewatpliwie najbardziej dojrzałym (choć - nie najobszerniejszym²) dziełem w dorobku Radosława Zenderowskiego. Uzyskała wyróżnienie w programie Monografie na rzecz Nauki Polskiej, obejmujacym publikacje $z$ zakresu nauk humanistycznych i społecznych. Wydanie książki było subwencjonowane przez Fundację na rzecz Nauki Polskiej - co samo w sobie jest jej znakiem jakości. Warunkiem uczestnictwa $\mathrm{w}$ tym programie jest bowiem zgłoszenie pracy cechującej się:

- „wysokim poziomem naukowym,

- odkrywczością założeń i wagą wyników,

- oryginalnością ujęcia,

- integralnościa tematyki i formy"3.

Ponadto oczekuje się, że „monografie nie będą miały charakteru wyłącznie specjalistycznego, ale że zainteresuja także szersze grono odbiorców śledzących postępy humanistyki”. Zdaniem Rady Wydawniczej (w składzie: Janusz Sławiński, Lech Szczucki,

\footnotetext{
1 R. Zenderowski: Nad Tatrami błyska się... Słowacka tożsamość narodowa $w$ dyskursie politycznym w Republice Słowackiej (1989-2004), Wydawnictwo Uniwersytetu Kardynała Stefana Wyszyńskiego, Warszawa 2007.

2 Rozprawa habilitacyjna liczy 588 stron.

3 Fundacja na rzecz Nauki Polskiej, program „Monografie” (http://www.fnp.org.pl/programy/aktualne_programy_fnp/wydawnictwa_i_konferencje).
} 
Wojciech Tygielski, Marek Ziółkowski) monografia Zenderowskiego $z$ naddatkiem spełniała wszystkie te warunki, skoro ja nie tylko zakwalifikowano do tego programu, ale także wyróżniono. Jej autor dołączył w ten sposób do szacownego grona najwybitniejszych uczonych, którzy przed nim publikowali w tej serii, takich jak np. Gerard Labuda, Jan Doktór, Andrzej Szahaj, Ryszard Nycz, Teresa Kostkiewiczowa, Henryk Domański, Marcin Kula.

Lektura ksiażki Religia a tożsamość narodowa... w pełni weryfikuje jej wysoką ocenę przez ekspertów Fundacji na rzecz Nauki Polskiej. Jej dojrzałość zdumiewa tym bardziej, że przecież książka wyszła spod pióra bardzo młodego badacza, choć mającego ogromny dorobek. Znajacc ten dorobek i obserwując $z$ bliska rozwój naukowy Zenderowskiego, można było się spodziewać podjęcia przez niego właśnie takiej, a nie innej problematyki. Od początku drogi naukowej nie ukrywał fascynacji Europa Środkowo-Wschodnia (EŚW) w wymiarze kulturowo-społeczno-politycznym: jej skomplikowaną historia i współczesnością, zwłaszcza przemianami ostatnich lat. Efektami prowadzonych $z$ pasja badań $w$ tej dziedzinie są dzieła będące podstawą kolejnych awansów naukowych: dysertacja doktorska poświęcona reintegracji miast podzielonych granica państwową na przykładzie Cieszyna (właśnie to miasto jest jego „mała ojczyzna”) i obszerna monografia habilitacyjna dotycząca słowackiej tożsamości politycznej. $Z$ perspektywy kilku lat widać, że także niektóre jego przedsięwzięcia naukowo-organizacyjne były etapami logicznie prowadzącymi do omawianej tu książki. Chodzi tu chociażby o zorganizowana przez niego w 2003 roku międzynarodową konferencję, na której uczeni $z$ sześciu państw tego regionu debatowali, czy kategoria EŚW jest wspólnota czy zbiorowością.

Wspomniana fascynacja (uważny czytelnik publikacji Zenderowskiego zauważy, że kocha on EŚW) nie przeszkadza mu w kompetentnym, obiektywnym ujmowaniu problematyki związku religii i tożsamości narodowej w tym regionie. Ów obiektywizm zasługuje szczególnie na podkreślenie, gdyż Autor dotyka przecież niezwykle delikatnej materii, w odniesieniu do której rzeczywiście trud- 
no zachować postawę niezaangażowanego obserwatora. Jedynie na marginesie, często w przypisach, pozwala sobie na wartościujące komentarze. Dotyczy to głównie tych fragmentów, w których z pasją rozwiewa różnego rodzaju szkodliwe mity i stereotypy, np. o rzekomo „odwiecznej wrogości” na Bałkanach czy o tym, iż „konflikt jugosłowiański był po prostu krwawym konfliktem religijnym”. Nie ukrywa dezaprobaty wobec „monopolu Zachodu na rozpowszechnianie "wiedzy" na temat poszczególnych regionów świata, której nieusuwalnym elementem jest specyficzna narracja majaca pośrednio udowadniać wyższość cywilizacyjna Zachodu i uzasadniać jego ingerencję w niemal każdym zakatku współczesnego świata" (s. 177, s. 408). Trudno zresztą nie zgodzić się z tymi krytycznymi uwagami.

Samego Zenderowskiego przed uproszczeniami i stereotypami uchroniła doskonała znajomość spraw EŚW. On „czuje” ten region, tzn. intuicyjnie bardzo trafnie identyfikuje ważne problemy badawcze, w ich rozwiazywaniu zaś nie pozwala sobie na wyprowadzenie na manowce zabarwionych ideologicznie półprawd. Ośmiela się przy tym polemizować $z$ uczonymi tej miary co Samuel Huntington czy Ernest Renan. Przekonująco pokazuje słabości Huntingtonowskiej teorii zderzenia cywilizacji. $Z$ kolei analizowany przez niego kazus boszniacki (3.3.1) unieważnia - jego zdaniem - znana tezę Renana, iż „Religia nie jest w stanie dostarczyć odpowiedniej podstawy dla konstytucji nowoczesnego obywatelstwa" (s. 175). Zenderowski zna EŚW $z$ autopsji, $z$ wielu podróży studyjnych, niezliczonych rozmów i „obserwacji uczestniczacej”. Jeśli dodać do tego skrupulatne ustalenie stanu badań, perfekcyjne opanowanie literatury przedmiotu, znajomość różnych teorii $z$ obszaru nauk społecznych na temat relacji religii i narodu, to nie dziwi końcowy efekt w postaci naprawdę oryginalnego dzieła naukowego.

Trudno wskazać jakieś luki w bardzo obszernej, zebranej na trzydziestu stronach (s. 271-300), wielojęzycznej bibliografii. Pretensję można zgłosić jedynie, że Zenderowski prawie nie zauważył kolegów $z$ własnego środowiska, których publikacje pośrednio 
lub bezpośrednio dotyczą omawianej przez niego problematyki. Zdumiewa to tym bardziej, że do wydania niektórych $z$ nich sam przyłożył niegdyś rękę, opracowując lub współredagując dzieła zbiorowe. Widocznie rzeczywiście pod latarnia jest najciemniej.

Lektura książki wciaga czytelnika. Imponuje żelazna logika wywodów. Zenderowski nie zbacza $z$ wyznaczonego kursu, przez cały czas pisze na temat. Nawet obszerne przypisy sa nie tyle dygresjami, ile szczegółowym uzupełnieniem jakiegoś ogólniejszego wątku. Rozważania Autora, choć oparte na solidnym zapleczu teoretycznym, bynajmniej nie sa jedynie ogólnoteoretyczne ani tym bardziej ogólnikowe. Każdy wyróżniony przez niego typ relacji między religia a etnosem odnajdujemy w zróżnicowanej mozaice rzeczywistości społeczno-kulturowej omawianego regionu. Odpowiedź na każde pytanie o przyczyny np. konfliktów czy o ich skutki, udzielana jest przez charakterystykę niezwykle trafnie dobranych przykładów danego stanu rzeczy.

Książka składa się ze wstępu, trzech rozdziałów, zakończenia, aneksu zawierajacego ciekawe mapy, bibliografii, streszczenia angielskiego, indeksów (osób i nazw) oraz spisów tabel i map. Końcowe, dodatkowe elementy, perfekcyjnie sporządzone, pomagaja w lekturze i pozwalaja szybko odszukać watki szczególnie interesujące czytelnika. Trzy główne rozdziały ksiaż̇ki - zatytułowane: 1. Rozróżnienia definicyjne 2. Kluczowe pytania 3. Próby odpowiedzi-dobrze porządkuja zawartość książki według klucza formalnego.

Niebanalnie napisany wstęp zachęca do dalszej lektury. Odpowiada on wszelkim rygorom wymaganym $\mathrm{w}$ pracach naukowych, a jednocześnie lekko się go czyta. W rozdziale pierwszym Autor przygotowuje sobie grunt podstawowych pojęć, wykorzystywanych następnie $\mathrm{w}$ zasadniczych rozważaniach na temat relacji między religia i etnosem. Wieloaspektowo definiuje: etniczność, religię, tożsamość narodowa, nacjonalizm, etnicyzacje religii i sakralizację etnosu. Demonstruje przy tym ogromna erudycję i znajomość najnowszej literatury światowej, a jednocześnie dużą suwerenność. Pokazuje mocne i słabe strony kolejnych ujęć, aby w koń- 
cu jednoznacznie przyjąc taką definicję, którą uznaje za najlepsza $\mathrm{w}$ perspektywie swojego zamierzenia badawczego, podajac racje przemawiające na rzecz właśnie takiego stanowiska.

Oczywiście, w odniesieniu do niektórych przyjętych przez niego definicji można zgłosić pewne wattpliwości. I tak np. nawiazując do kilku aspektów religii wyróżnionych przez Jonathana Foxa, Zenderowski zaznacza, że religia będzie go interesowała "głównie w aspekcie instytucjonalnym" (s. 25). Nie kwestionujacc wagi tego aspektu w dalszych badaniach, wydaje się jednak, że w relacji do etniczności równie ważne sa inne, wymienione przez niego, jak chociażby zasady i standardy zachowań wynikajace $z$ prawd religijnych czy też źródło legitymizacji pewnych działań - o czym zreszta jest mowa w tekście. Drobne uzupełnienie zgłaszam następnie wobec skądinąd dobrze dobranego przykładu Góry św. Anny jako miejsca świętego, „o prawo własności którego [...] rywalizuja dwa narody” (s. 41, s. 52). Otóż obok tej rywalizacji niewatpliwie jest to także miejsce pojednania. Trudno przecenić jego znaczenie integracyjne.

Generalnie jednak tekst rozdziału pierwszego zawiera wiele ważnych twierdzeń, np. o nacjonalizmie jako m.in. reakcji na sekularyzację i desakralizację życia społecznego (s. 46); ciekawych tez, $\mathrm{np}$. dotyczacych ambiwalentnego zwiazku religii i nacjonalizmu (s. 47); interesujacych hipotez, np. o geograficznym zróżnicowaniu tego związku (s. 55). Każdy, choćby tylko mimochodem podjęty watek rozważań budzi zainteresowanie. Dotyczy to np. zasygnalizowanego przez Autora pokrewieństwa problematyki nacjonalizmu jako swego rodzaju „świeckiej religii” $z$ problematyka „religii obywatelskiej” od dawna obecną w dyskursie filozoficznym, ale też politologicznym.

Krótki rozdział drugi zawiera listę pytań artykułujacych ważne problemy badawcze. Stanowi on zapowiedź dalszych rozważań. Każde $z$ sześciu postawionych tu we właściwej kolejności pytań jest podejmowane w poszczególnych punktach rozdziału trzeciego. Choć za wyodrębnieniem tego rozdziału przemawia formalna elegancja struktury książki, jego (szczupła) treść mogłaby się też 
znaleźć we wstępie. Oczywiście wtedy podpunkty rozdziału trzeciego musiałyby stanowić odrębne rozdziały.

Kluczowy w omawianej ksiażce rozdział trzeci otwiera odpowiedź na pytanie o przyczyny wpływu religii na kształtowanie tożsamości narodowych (3.1). Zenderowski zwraca uwagę na: substytutywna rolę Kościołów w stosunku do nieistniejącej państwowości, rywalizację Kościoła i państwa o „rząd dusz” w okresie komunizmu, znaczenie Kościołów dla tożsamości mniejszości narodowych oraz rolę religii na pograniczu wyznaniowym. Trudno do tej kompleksowej charakterystyki cokolwiek jeszcze dodać, tym bardziej że Autor ujmuje swoje rozważania na szerokim tle historycznym. Jedynie czasem pozwala sobie na gorzkie (niestety, prawdziwe) uwagi np. kiedy przypomina, że spośród państw naszego regionu Polska najkrócej była pozbawiona własnego państwa, a zatem nieuzasadnione jest „powszechne biadolenie na destruktywne dziedzictwo zaborów, mające w założeniu rozgrzeszać $z$ wszelkiej, także obiektywnie zawinionej nieudolności i partactwa” (s. 65).

Zakładając słusznie, że inne jest znaczenie religii we wspólnotach lub narodach jednokonfesyjnych, a inne - w wielokonfesyjnych, Zenderowski odrębnie omawia te kategorie zwiąków religii i etnosu (3.2.1 i 3.2.2). Wśród przyczyn mniejszej odporności prawosławia na komunizm niż katolicyzmu i protestantyzmu podaje m.in. brak zaangażowania społecznego Kościołów prawosławnych (s. 93). Należałoby tu dodać, że brak ten dotyczy również nauczania społecznego. Nie kwestionujacc znaczenia tego czynnika, rozstrzygające wydaje się jednak - przytaczane zresztą wcześniej - tłumaczenie Bogdana Cywińskiego, który główna przyczynę zróżnicowanego stopnia oporu wobec komunizmu widzi w odrębnej duchowości. Katolików, a tym bardziej protestantów, cechuje mianowicie aktywistyczny stosunek do świata, prawosławnych zaś - „dystans wobec wszelkiej doczesności”. $Z$ tej perspektywy „swiat w mniejszym stopniu jest do naprawienia ludzkim wysiłkiem" (s. 92).

Oryginalne i odkrywcze sa spostrzeżenia na temat religii i języka (s. 132 i nast.). Zenderowski zasadnie podważa tzw. zasadę lingwi- 
styczną w analizie procesów narodowotwórczych w EŚW. Odważnie polemizuje $z$ autorytetami $w$ dziedzinie badań etnicznych tej miary, co Józef Chlebowczyk, słusznie upominając się o dowartościowanie czynnika religijnego jako niezwykle istotnego - zwłaszcza $\mathrm{w}$ procesie odróżniania się od innych narodów. W punkcie omawiajacym znaczenie religii we wspólnotach etnicznych (narodach) wielokonfesyjnych na uwagę zasługuje trafny dobór „przypadków”. Wybór Albanii, Słowacji i Łużyc daje Autorowi możliwość prezentacji kilku modeli tworzenia nowoczesnej tożsamości narodowej $\mathrm{w}$ wielowyznaniowej grupie etnicznej.

W trakcie lektury zaskakują wyjaśnienia, które daja do myślenia. Jednym $z$ nich jest ostrożnie sformułowana teza dotycząca unitów, która dobrze tłumaczy obcość tej grupy wyznaniowej: i względem prawosławia, i katolicyzmu. „Wydaje się, że podstawowa "winą" unitów jest to, że ich wyznanie oraz sama obecność zaciera "Świętą" granicę między dwiema cywilizacjami: zachodnia i prawosławną" (s. 165).

Uczciwe intelektualne zmaganie się $z$ materia relacji religia-naród owocuje u Zenderowskiego rzetelnymi odpowiedziami na wiele postawionych pytań. Jednocześnie pojawiają się nowe perspektywy badawcze. Autor zdaje sobie sprawę, że w jednej książce nie będzie $\mathrm{w}$ stanie na nie odpowiedzieć, ale sygnalizuje te problemy, rysując $\mathrm{w}$ ten sposób innym (lub sobie) dalsze plany badawcze. Oto wybrane przykłady:

- Zakładając duży wpływ religii na tożsamość narodową, zasadnie pyta (powołując się na niektórych socjologów), czy nie należy oczekiwać, że efektem procesów sekularyzacji będzie naruszenie tożsamości narodowej (s. 136-137).

- Zauważając rozpad i zranienia, wskutek „nachalnej nacjonalistycznej propagandy”, wielu małżeństw mieszanych, w których dochodziło do spotkania różnych tożsamości etniczno-religijnych, np. w Czechosłowacji czy Jugosławii, podpowiada politologom, aby więcej uwagi poświęcili „temu aspektowi integracji i dezintegracji społecznej w byłych wielonarodowych państwach Europy Środkowo-Wschodniej" (s. 166). 
- Omawiając z kolei czynniki przesadzające o emancypacji w XIX i XX wieku Mazurów $z$ etnosu i narodu polskiego, zwraca uwage nie tylko na religię, ale także na sprawy społeczno-ekonomiczne. Właśnie czynnik ekonomiczny uznaje za „wyjątkowo zaniedbany $\mathrm{w}$ badaniach nad XIX i XX-wiecznym nacjonalizmem i konfliktami zbrojnymi tego okresu" (s. 172).

- Pozostawia też otwarte ważne kwestie egzystencjalne, filozoficzne, co świadczy o jego uczciwości intelektualnej. Chodzi tu np. o pytania: „jak to możliwe, że ideologia nacjonalistyczna okazuje się silniejsza od osobistych pozytywnych doświadczeń w obcowaniu z ludźmi odmiennymi pod względem religijnym i narodowym. Dlaczego pamięć dobrych relacji $z$ "tym Innym" [...] potrafi w bardzo krótkim czasie ustapić miejsca fantastycznym i szalonym wizjom nacjonalistycznych elit? Dlaczego realne życie przegrywa $z$ ideologią?" (s. 167-168). Jak widać, sa to $\mathrm{w}$ gruncie rzeczy pytania o geneze $i$ istotę zła, wobec których przedstawiciel nauk społecznych, uzbrojony empiryczna metodologia, rzeczywiście pozostaje bezradny.

Kolejna kwestia podejmowana w ksiażce dotyczy religii jako fundamentu dla nowo kształtującej się tożsamości etnicznej (3.3). Autor - na przykładzie m.in. Boszniaków, Pomaków (Bułgaromahometan) i Staroobrzędowców - weryfikuje hipotezę o przemożnym wpływie religii na wyodrębnienie się tych tożsamości. Omawia przebieg i okoliczności owego procesu. Porusza jednocześnie kilka kwestii, na które rzadko zwraca się uwage w naukach o polityce. Analizując znaczenie i sposób używania takich nazw własnych jak np. Bośniacy - Boszniacy (s. 173 i nast.), Pomacy (s. 192) wskazuje mianowicie, że skomplikowane spory lingwistyczne de facto sa sporami o charakterze politycznym. Interesujaco pisze też o tzw. efekcie mniejszej różnicy jako źródle wrogości Bułgarów do Pomaków. $Z$ powodzeniem można tę znana etnologom prawidłowość odnieść do innych nacji. Przecież właśnie relatywne podobieństwo różnych grup etnicznych rodzi agresję $-z$ obawy przed zamazaniem granicy własnej tożsamości. Konstatacja, że dla chrześcijan Pomacy, owszem, są Bułgarami, ale nie do końca; dla 
Turków zaś - nie całkiem prawdziwymi muzułmanami, okazuje się egzystencjalnie gorzko prawdziwa. Zdanie „Pomacy, Goranie/ Gorańcy, Boszniacy, Torbesze skazani sa na niepewna egzystencję "na miedzy", między narodami" (s. 202) przypomina rozterki znanego uczonego i poety, Janusza Pasierba, który, będąc kiedyś w Lizbonie, zapisał w notatniku: „W Polsce jestem Europejczykiem, tu zaś Polakiem, jak zając na miedzy"4.

Prezentując dalej przypadek czeski (3.4) Zenderowski przekonująco pokazuje, że nawet narody dalece zlaicyzowane potrzebuja tradycji religijnej - choćby i zeświecczonej - w celu budowania tożsamości narodowej. Interesująco omawia tu przyczyny i przejawy czeskiego antykatolicyzmu. Charakteryzuje też zlaicyzowany i „upaństwowiony” husytyzm. „Laickie chrześcijaństwo Czechów” (s. 216) nasuwa skojarzenia $z$ teologiczna koncepcja anonimowego chrześcijaństwa Karla Rahnera. Nawiasem mówiąc, trudno nie poprzeć wyartykułowanego w zakończeniu (s. 249) i faktycznie przez Autora realizowanego metodologicznego postulatu multidyscyplinarnego podejścia do badanych zagadnień. Tyle tylko że listę dyscyplin, które moga wnieść wkład „w wyjaśnienie fenomenu związku religii i tożsamości narodowej w Europie Środkowo-Wschodniej" należałoby uzupełnić. Mowa tu mianowicie o socjologii religii, politologii, antropologii, etnologii, literaturoznawstwie i filozofii. Brakuje natomiast teologii czy historii sztuki.

Rozważając rolę religii w konfliktach etnicznych (3.5), Autor odrębnie omawia konflikt w warunkach „zderzenia” różnych religii (3.5.1) i konflikt etniczny w obrębie tej samej wspólnoty religijnej (3.5.2). Zastanawiajacc się, czy religia jest przyczyna, czy „wzmacniaczem" konfliktów etnicznych (3.5.3), przekonujaco pokazuje prawdziwość drugiego członu tej alternatywy. Przy okazji falsyfikuje kolejne uproszczenie lansowane nie tylko w mediach „szukajacych łatwych wyjaśnień etnicznej nienawiści”, ale i w literaturze naukowej: „o religii jako "generatorze" wrogości etnicznej” (s. 230).

${ }_{4}^{4}$ J. Pasierb, Człowiek $i$ jego świat $w$ sztuce religijnej renesansu, Bernardinum, Pelplin Warszawa 1999, s. 119. 
Interesującym dopełnieniem całości są refleksje na temat toposu religijnego i toposu etnicznego (3.6). Uważny czytelnik stron poświęconych etnosymbolicznemu wymiarowi światyni (3.6.1), architektonicznemu „wyścigowi do nieba” (3.6.2), planowemu niszczeniu świątyń (3.6.3) oraz cmentarzom jako symbolom etnicznym (3.6.4) bez trudu znajdzie w polskiej przestrzeni etnoreligijnej dodatkowe potwierdzenie tez prezentowanych $\mathrm{w}$ tym fragmencie książki.

Dodatkowym uzasadnieniem bardzo wysokiej oceny recenzowanej książki jest ogromna kultura, $z$ jaka traktuje Autor trudna problematykę zwiąków religii i etnosu. Stara się nie wartościować - nie chwalić i nie potępiać, ale jedynie opisywać, porządkować, typologizować, wyjaśniać. Obca jest mu i apologetyka, i moralistyka. Słusznie bez komentarza pozostawia niekiedy wstrzasajace fakty czy bulwersujące wypowiedzi fanatycznych przywódców religijnych i polityków. Pytanie o moralny wymiar opisywanych zjawisk pozostawia otwarte m.in. dlatego, że - jak wprost zaznacza - „niezwykle trudno jest jednoznacznie na nie odpowiedzieć" (s. 248). Jeśli już kogoś ocenia, to nie tyle aktorów opisywanych fenomenów, ile jedynie autorów, odpowiedzialnych za rozpowszechnianie fałszywych, niesprawiedliwych sąów.

Jak już zaznaczyłam wyżej, książkę można polecić nie tylko wąskiemu kręgowi specjalistów różnych dyscyplin nauk społecznych i humanistycznych. Przystępny język, dyscyplina wywodów, elegancja stylistyczna, dzięki której uporządkowana myśl zostaje ubrana w prosta i piękna szatę językowa, przesadzaja o tym, że do lektury można zachęcić szerokie grono odbiorców. Tym bardziej że publikacja została starannie przygotowana graficznie i redakcyjnie, korzystnie kontrastując $z$ wydawanymi dziś $\mathrm{w}$ pośpiechu książkowymi bublami.

\section{Aniela Dylus}

Aniela Dylus - filozof, profesor zwyczajny, pracuje na Uniwersytecie Kardynała Stefana Wyszyńskiego w Warszawie. 